\title{
Adjoint sensitivity of global cloud droplet number to aerosol and dynamical parameters
}

\author{
V. A. Karydis ${ }^{1}$, S. L. Capps $^{2}$, A. G. Russell ${ }^{3}$, and A. Nenes ${ }^{1,2}$ \\ ${ }^{1}$ School of Earth and Atmospheric Sciences, Georgia Institute of Technology, Atlanta, GA, USA \\ ${ }^{2}$ School of Chemical and Biomolecular Engineering, Georgia Institute of Technology, Atlanta, GA, USA \\ ${ }^{3}$ School of Civil and Environmental Engineering, Georgia Institute of Technology, Atlanta, GA, USA \\ Correspondence to: A. Nenes (athanasios.nenes@gatech.edu)
}

Received: 11 April 2012 - Published in Atmos. Chem. Phys. Discuss.: 10 May 2012

Revised: 22 August 2012 - Accepted: 19 September 2012 - Published: 4 October 2012

\begin{abstract}
We present the development of the adjoint of a comprehensive cloud droplet formation parameterization for use in aerosol-cloud-climate interaction studies. The adjoint efficiently and accurately calculates the sensitivity of cloud droplet number concentration (CDNC) to all parameterization inputs (e.g., updraft velocity, water uptake coefficient, aerosol number and hygroscopicity) with a single execution. The adjoint is then integrated within three dimensional (3-D) aerosol modeling frameworks to quantify the sensitivity of CDNC formation globally to each parameter. Sensitivities are computed for year-long executions of the NASA Global Modeling Initiative (GMI) Chemical Transport Model (CTM), using wind fields computed with the Goddard Institute for Space Studies (GISS) Global Circulation Model (GCM) II', and the GEOS-Chem CTM, driven by meteorological input from the Goddard Earth Observing System (GEOS) of the NASA Global Modeling and Assimilation Office (GMAO). We find that over polluted (pristine) areas, CDNC is more sensitive to updraft velocity and uptake coefficient (aerosol number and hygroscopicity). Over the oceans of the Northern Hemisphere, addition of anthropogenic or biomass burning aerosol is predicted to increase CDNC in contrast to coarse-mode sea salt which tends to decrease CDNC. Over the Southern Oceans, CDNC is most sensitive to sea salt, which is the main aerosol component of the region. Globally, CDNC is predicted to be less sensitive to changes in the hygroscopicity of the aerosols than in their concentration with the exception of dust where CDNC is very sensitive to particle hydrophilicity over arid areas. Regionally, the sensitivities differ considerably between the two frameworks and quantitatively reveal why the models differ considerably in their indirect forcing estimates.
\end{abstract}

\section{Introduction}

As cloud condensation nuclei (CCN), aerosols modulate the radiative properties of clouds by altering CDNC, droplet effective radius, precipitation, and cloud albedo. Within global climate models (GCMs), the aerosol-cloud link is modeled by direct application of a cloud droplet formation parameterization (Boucher and Lohmann, 1995; Abdul-Razzak and Ghan, 2000; Nenes and Seinfeld, 2003; Segal and Khain, 2006), or using the latter within a two moment framework (Seifert and Beheng, 2006; Morrison and Gettelman, 2008).

Quantifying the sensitivity of climate state to model parameters is at the heart of any climate impact assessment. It is almost exclusively evaluated by "brute force methods", in which relevant parameters are independently perturbed and the model response is quantified in separate simulations. For aerosol-cloud-climate interaction studies, parameters related to aerosol emissions, hygroscopicity and dynamical forcing at cloud base are most often perturbed. For example, Spracklen et al. (2005), by using the global aerosol microphysics model GLOMAP and individually perturbing the process parameters, conclude that uncertainties in aerosol microphysical processes have a larger effect on global sulfate and sea salt derived condensation nuclei $(\mathrm{CN})$ and $\mathrm{CCN}$ concentrations than uncertainties in present-day sulfur emissions. Sotiropoulou et al. $(2006,2007)$ combined the GISS GCM Model II' with explicit treatment of aerosol-cloud interactions and in-situ observations to estimate the uncertainty of shortwave cloud radiative forcing and autoconversion rate associated with the application of Köhler theory. Their study suggested that this error is not significant compared to errors in the size distribution or unresolved subgrid cloud dynamics. 
Ervens et al. (2007) used in-situ data from the ICARTT field study to determine the main parameters required for achieving CCN closure; they found that knowledge of the aerosol size distribution along with a simple representation of aerosol composition (soluble fraction) was adequate, especially at high supersaturations. Ervens et al. (2010) found that while freshly-emitted pollution aerosol could not be represented without knowledge of more complex composition, $\mathrm{CCN}$ derived from aged aerosols could be predicted within a factor of two with any mixing state assumption. Furthermore, a factor of two uncertainty in $\mathrm{CCN}$ concentration was found to yield $\sim 15 \%$ uncertainty in CDNC. Korhoren et al. (2010), using GLOMAP, studied the sensitivity of CDNC, aerosol size distribution, and natural aerosol processes to sea salt emissions. Woodhouse et al. (2010) used GLOMAP to calculate the sensitivity of CCN to changes in dimethyl-sulfide (DMS) emission using multiple present-day and future sea-surface DMS climatologies. Liu and Wang (2010) used the NCAR Community Atmosphere Model (CAM) to examine the sensitivity of global CCN and aerosol indirect forcing to the hygroscopicity of primary and secondary organic aerosols. Barahona et al. (2011) used the NASA GMI model to calculate the relative change of CDNC associated with diabatic activation. The largest relative change of CDNC was found in the tropics, downwind of large emission sources, and in South America and North Africa where clouds with moderate CDNC $\left(100-300 \mathrm{~cm}^{-3}\right)$ are present. Alterskjær et al. (2012) investigated the effect of sea salt injections on marine clouds, using data of cloud optical depth, liquid cloud fraction, and CDNC from satellite retrievals and compared the derived sensitivity to a corresponding estimate from the Norwegian Earth System Model (NorESM).

The studies presented above are in no way a thorough literature review on aerosol-cloud interactions but are examples where sensitivity of $\mathrm{CCN}$ (or CDNC) to a parameter is estimated by finite differencing discrete model evaluations for each parameter investigated. To increase efficiency of these investigations and to assess the role of nonlinearity in cloud droplet activation, approaches other than finite differences have been employed in recent years. Anttila and Kerminen (2007) investigated the role of Aitken mode particles in continental convective cloud formation with a probabilistic collocation method, which approximates the function of the parameterization with polynomials. Haertner et al. (2009) combined single and multiple parameter perturbation experiments to explore the parametric uncertainty in aerosol activation in ECHAM5. Motivated by testing an inverse modeling framework for aerosol indirect effects, Partridge et al. (2011) developed a response surface model for an adiabatic cloud parcel model, which provides a 2-D representation of the role of input parameters (e.g., updraft, surface tension) on the cloud droplet number. Most recently, Lee et al. (2011b) developed and used a Gaussian process emulator for the GLOMAP global model to estimate the CCN sensitivity to model parameters (e.g., oxidation activation parameter, mass accommodation coefficient) in polluted and remote marine environments as a function of altitude.

Alternatively, sensitivities can be explicitly calculated. For example, Rissman et al. (2004) used a droplet formation parameterization to derive analytical expressions of the sensitivity of CDNC to aerosol and dynamical parameters. These expressions were then used to compare the sensitivity of droplet number to aerosol chemical composition, updraft velocity and size distribution parameters. In particular, they demonstrated that the effect of aerosol composition on $\mathrm{CDNC}$ can be as much as 1.5 times more important than the corresponding effect of updraft velocity. Although comprehensive, this approach requires significant development, and it may not be feasible for more complex process formulations. Alternately, the adjoint technique is an attractive approach for computing sensitivities as it accurately and efficiently quantifies the required perturbations in each control parameter for a requisite change in a calculated quantity in a single execution (Giering, 2000). When applied to a cloud droplet formation parameterization, an adjoint model quantifies the sensitivities of CDNC, $N_{\mathrm{d}}$, to all input parameters, $I$ (i.e., $\frac{\partial N_{\mathrm{d}}}{\partial I}$ ). The primary challenge remains the effort required to develop the adjoint, although in many cases automatic differentiation tools can considerably facilitate adjoint development from existing codes.

The meteorological and oceanographic modeling communities initiated the extension of the adjoint method, originally developed in control theory (Lions, 1971), to geochemical applications (Ghil and Malanotterizzoli, 1991). Adjoint techniques are a primary means of estimating model parameters and inputs (e.g., initial conditions) by assimilation of observations in accordance with model physics in these fields (Sasaki, 1970; Le Dimet and Talagrand, 1986). Development of adjoint methods for climate models began with Hall (1986), who demonstrated the utility of this method in assessing climate sensitivity to model parameters (e.g., doubling of atmospheric $\mathrm{CO}_{2}$, increase of 0.03 in surface albedo). Investigations of parameter (e.g., emissions rates, rate constants) importance in CTMs have become possible with increased computational resources and development of automatic differentiation tools that facilitate formulation of adjoint models (e.g., TAPENADE; Hascoët and Pascual, 2004). Sensitivities of gaseous species concentrations have been widely investigated (Menut et al., 2000; Vukićević and Hess, 2000; Sandu et al., 2005; Hakami et al., 2005; Martien and Harley, 2006) and recently, sensitivities of aerosol species concentrations have been investigated with this technique (Hakami et al., 2005; Henze et al., 2009; Kopacz et al., 2011; Capps et al., 2012). Adding the sensitivity of cloud droplet formation and propagating aerosol sensitivities thereon considerably augment the capabilities of these adjoint model frameworks and, if included in coupled climate models, could offer a unique insight into what drives CDNC and indirect forcing variability. 
Here we present the development of the adjoint of the $\mathrm{Ku}$ mar et al. (2009) cloud droplet formation parameterization. We then demonstrate its capabilities by driving it with output from the NASA Global Modeling Initiative (GMI) and GEOS-Chem 3-D CTMs. Thus, we produce the global sensitivity field of CDNC to updraft velocity, uptake coefficient, hygroscopicity of soluble particles, adsorption parameters of insoluble particles, and aerosol concentration. The sensitivities are then used to explain sources and differences of CDNC predictions and indirect forcing assessments.

\section{Development of the cloud droplet formation parameterization adjoint}

\subsection{The cloud droplet formation parameterization}

The calculation of CDNC is carried out in two conceptual steps (Fig. 1). The first step involves the determination of the "CCN spectrum", $F^{\mathrm{s}}(s)$, which is the number of $\mathrm{CCN}$ that can activate to form droplets at a certain level of supersaturation. The second step is to determine the maximum supersaturation, $s_{\max }$, that develops in the ascending cloudy parcels so that the droplet number that forms is equal to $F^{\mathrm{s}}\left(s_{\max }\right)$. $F^{\mathrm{s}}(s)$ is computed based on Kumar et al. (2009) in which soluble particles are described by Köhler theory, where CCN activity is determined solely by the amount of solute present. Insoluble particles also contribute $\mathrm{CCN}$; their activity is determined by the amount of adsorbed water on the insoluble surface of the particles and the vapor pressure depression from any soluble salts present (Kumar et al., 2011a, b). $F^{\mathrm{s}}(s)$ for an external mixture of lognormal particle size distributions is given by:

$F^{\mathrm{s}}(s)=\int_{0}^{\mathrm{s}} n^{\mathrm{s}}(s) \mathrm{d} s=\sum_{i=1}^{n_{m}} \frac{N_{i}}{2} \operatorname{erfc}\left[-\frac{\ln \left(\frac{s_{\mathrm{g}, i}}{s}\right)}{x \sqrt{2} \ln \left(\sigma_{i}\right)}\right]$

where $s_{\mathrm{g}, i}$ is the critical supersaturation of the particle (i.e., the level of supersaturation at which the particle activates into a cloud droplet) with a diameter equal to the geometric mean diameter of the mode $i, \sigma_{i}$ is the geometric standard deviation for mode $i$, and $x$ is an exponent that expresses the aerosol-water vapor interactions. In particular, for hygroscopic aerosols, following Köhler theory, $x=-\frac{3}{2}$ (Fountoukis and Nenes, 2005), while in adsorption theory based on the Frenkel-Halsey-Hill (FHH) isotherm, $x$ varies between -0.8 and -1.2 and depends on the adsorption parameters, $A_{\mathrm{FHH}}$ and $B_{\mathrm{FHH}}$ (Kumar et al., 2009, 2011a). Kumar et al. (2011b) also extended the FHH framework to include a soluble fraction to represent aged dust, so that $x$ also depends on the soluble fraction.

The maximum supersaturation, $s_{\max }$, is calculated from an equation that expresses the supersaturation tendency in the ascending cloudy air parcels (Nenes and Seinfeld, 2003; Barahona and Nenes, 2007),

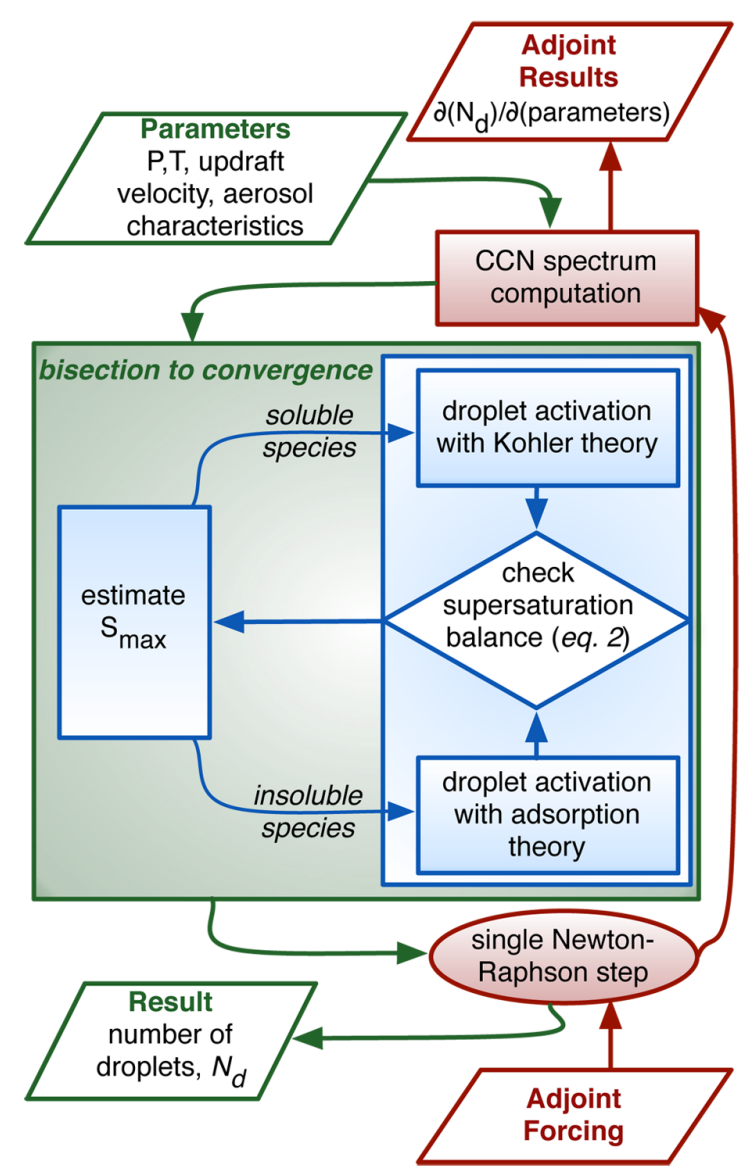

Fig. 1. Flow diagram of the Kumar et al. (2009) parameterization algorithm and its adjoint. The adjoint calculation steps are illustrated in red.

$\frac{2 a V}{\pi \gamma \rho_{\mathrm{w}}}-G s_{\max } I\left(0, s_{\max }\right)=0$

where $V$ is the updraft velocity, $\rho_{\mathrm{w}}$ is the density of water, and other parameters $(a, \gamma, G)$ are defined as in Barahona and Nenes (2007). $I\left(0, s_{\max }\right)$ is known as the "condensation integral" (Barahona et al., 2010; Barahona and Nenes, 2007; Kumar et al., 2009), and it expresses the condensational depletion of supersaturation upon the growing droplets at the point of $s_{\max }$ in the cloud updraft. Equation (2) is solved numerically. Once $s_{\max }$ is determined, the CDNC is just the value of the $\mathrm{CCN}$ spectrum at $s_{\max }$ (i.e., $N_{\mathrm{d}}=F^{\mathrm{s}}\left(s_{\max }\right)$ ) from Eq. (1).

\subsection{Development of the adjoint}

The adjoint model corresponding to the parameterization of Sect. 2.1 efficiently determines the sensitivity of the CDNC with respect to each input parameter (updraft velocity, uptake coefficient, aerosol number, hygroscopicity of soluble aerosol species, adsorption parameters of insoluble aerosols) 
(Fig. 1). The adjoint is developed assuming the hydrophilicity of insoluble particles is driven solely by the adsorption parameters (leaving variations in the dust soluble fraction as presented by Kumar et al. (2011b) for a future study). One call of the adjoint requires a forward model execution (Fig. 1, green and blue arrows) followed by reverse calculation of the same functions and the associated derivative calculations (Fig. 1, red elements). Thus, a single execution of the parameterization adjoint calculates this array of sensitivities by propagating an adjoint forcing through a reverse execution of the derivatives of the model equations. Generally, the code is augmented for each elementary calculation in the model by applying the chain rule of derivative calculus with the automatic differentiation tool TAPENADE (Hascoët, 2004).

The approach outlined above applies only to code with explicit functional dependence of results on intermediate or input parameters. Since the calculation of the maximum supersaturation, $s_{\max }$, requires the implicit bisection method, direct calculation of sensitivities is precluded. Capps et al. (2012) also encountered this issue when developing the adjoint of the ISORROPIA thermodynamics code and addressed it by applying the explicit Newton-Raphson (N-R) method after convergence of bisection (Bartholomew-Biggs, 1998). The adjoint was then developed for the latter step for sensitivity calculations as follows. TAPENADE was used to create the tangent linear model of the maximum supersaturation calculation. This code is then used to calculate the derivative of the objective function of the bisection method with respect to the converged root value. With this sensitivity, a single N-R step is taken after bisection convergence in the forward model calculation. The reverse execution of the adjoint model propagates derivatives only through the N-R step (not bisection) and then through the derivatives of the CCN spectrum computation (Fig. 1, red elements). Thereby, after calculation of the forward model at the specified parameter values, the derivative of CDNC with respect to each intermediate variable in the code is computed and passed through the augmented code in reverse order. The result is the efficient, simultaneous calculation of the adjoint sensitivities of $\mathrm{CDNC}$ with respect to the parameterization inputs.

\subsection{Evaluation of droplet parameterization adjoint}

The accuracy of the adjoint model is extensively verified against forward model sensitivities (Fig. 2) calculated using central finite differences (brute force). The finite difference calculation requires an additional forward model evaluation per input parameter, using a $1 \%$ relative perturbation in each input parameter. To cover a wide range of conditions, monthly averaged aerosol concentrations (spanning one year) from every grid cell of the GMI model (Sect. 3.1) is used as input to the adjoint of the cloud droplet formation parameterization. In addition, ten different updraft velocities were used ranging from $0.1 \mathrm{~m} \mathrm{~s}^{-1}$ to $5 \mathrm{~m} \mathrm{~s}^{-1}$, five uptake coefficients ranging from 0.06 to 1 , and three $A_{\mathrm{FHH}}$ and $B_{\mathrm{FHH}}$

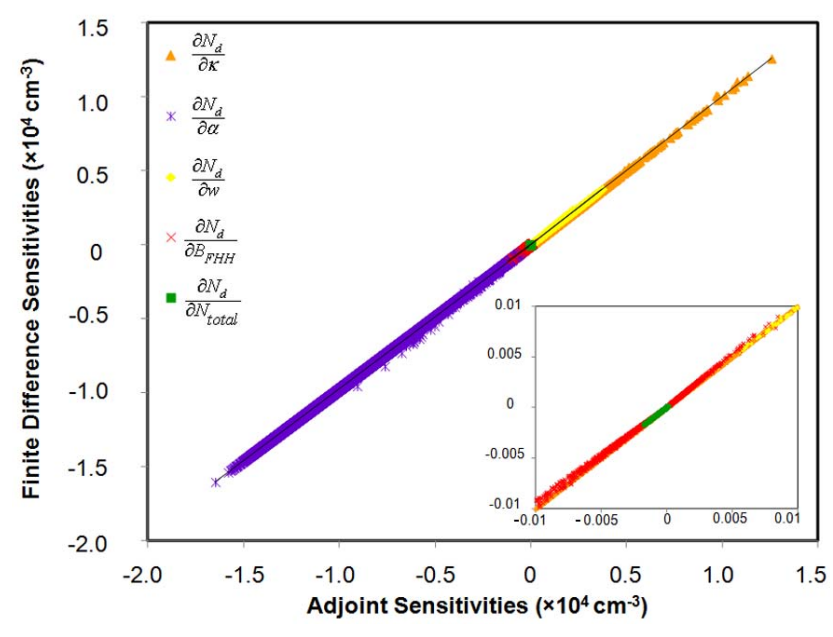

Fig. 2. Adjoint cloud droplet number concentration sensitivities compared to finite difference sensitivities. The inner plot zooms in the -0.01 to 0.01 range. $R^{2}$ in all parameters range from 0.9986 to 1.0 .

adsorption parameters ranging from 1.75 to 2.75 and from 1.1 to 1.3 , respectively. The adjoint sensitivities are virtually identical to the finite difference sensitivities $\left(R^{2}>0.99\right)$.

\section{Application of droplet parameterization adjoint in three dimensional model frameworks}

\subsection{The NASA Global Modeling Initiative (GMI)}

The GMI 3-D global CTM (http://gmi.gsfc.nasa.gov) was originally described by Rotman et al. (2001) and Considine et al. (2005). The aerosol module used in this study includes primary emissions, gas phase and aqueous phase chemistry with one hour time step, wet and dry deposition, and hygroscopic growth (Liu et al., 2005). The horizontal resolution is $4^{\circ} \times 5^{\circ}$ latitude by longitude and the vertical resolution has 23 layers and a model top at $0.1 \mathrm{hPa}$. The model time step for chemistry is one hour. Winds, temperatures, and other meteorological quantities used in this work are taken from the GISS GCM II' and represents the period from January 1997 to February 1998 with the first two months used to spinup the model. Emissions are provided by Liu et al. (2005) and include $\mathrm{SO}_{2}$, DMS, $\mathrm{H}_{2} \mathrm{O}_{2}$, black carbon, organic carbon, mineral dust, and sea salt based on the draft IPCC-specified 2000 scenario. The global emissions of $\mathrm{SO}_{2}, \mathrm{BC}$, and $\mathrm{OC}$ in GMI are $73.8 \mathrm{Tg}_{-} \mathrm{S} \mathrm{yr}^{-1}, 13.5 \mathrm{Tg}_{-} \mathrm{C} \mathrm{yr}^{-1}$ and $111.2 \mathrm{Tg}-\mathrm{C}$ $\mathrm{yr}^{-1}$, respectively.

Monthly-averaged mass concentrations of aerosols are computed from GMI and are given as an input to the cloud droplet formation parameterization. Aerosols are distributed in four modes: sulfate, organic mass and black carbon from fossil fuel combustion; organic mass and black carbon from biomass burning; sulfate and sea salt from marine processes; 
Table 1. Size distribution parameters applied to aerosol populations from GMI and GEOS-Chem models.

\begin{tabular}{|c|c|c|c|c|c|c|}
\hline Aerosol type & Aerosol components & $\begin{array}{l}\text { Density } \\
\left(\mathrm{gcm}^{-3}\right)\end{array}$ & $\begin{array}{l}\text { Median } \\
\text { diameter } \\
(\mu \mathrm{m})\end{array}$ & $\begin{array}{l}\text { Geometric } \\
\text { standard } \\
\text { deviation }\end{array}$ & $\begin{array}{l}\text { Number } \\
\text { fraction }\end{array}$ & Reference \\
\hline $\begin{array}{l}\text { Anthropogenic, } \\
\text { Biomass Burning }^{\text {a }}\end{array}$ & $\begin{array}{l}\text { Sulfate } \\
\text { Nitrate } \\
\text { Ammonium } \\
\text { Organic Carbon } \\
\text { Black Carbon }\end{array}$ & $\begin{array}{l}1.77 \\
1.725 \\
1.75 \\
1.2 \\
1.5\end{array}$ & 0.1 & 1.9 & 1 & $\begin{array}{l}\text { Chuang et al. (1997); } \\
\text { Radke et al. (1988) }\end{array}$ \\
\hline Biomass Burning $b$ & $\begin{array}{l}\text { Organic Carbon } \\
\text { Black Carbon }\end{array}$ & $\begin{array}{l}1.2 \\
1.5\end{array}$ & 0.16 & 1.65 & 1 & Anderson et al. (1996) \\
\hline Marine & $\begin{array}{l}\text { Sulfate } \\
\text { Nitrate } \\
\text { Sea Salt }\end{array}$ & $\begin{array}{l}1.77 \\
1.725 \\
2.2\end{array}$ & $\begin{array}{l}0.018 \\
0.075 \\
0.62\end{array}$ & $\begin{array}{l}1.4 \\
1.6 \\
2.7\end{array}$ & $\begin{array}{l}0.81 \\
0.18 \\
0.01\end{array}$ & Lance et al. (2004) \\
\hline Mineral Dust & Dust & 2.6 & $\begin{array}{l}0.16 \\
1.4 \\
10\end{array}$ & $\begin{array}{l}2.1 \\
1.9 \\
1.6\end{array}$ & $\begin{array}{l}0.93 \\
0.07 \\
3 \times 10^{-6}\end{array}$ & D'Almeida et al. (1987) \\
\hline
\end{tabular}

a The biomass burning aerosols participate in the first mode only for the GEOS-Chem application.

${ }^{\mathrm{b}}$ For the GEOS-Chem application, mode 2 is not used as the biomass burning aerosols are in the first mode together with the anthropogenic aerosols.

and mineral dust. Aerosols from the first three modes are assumed to follow Köhler theory whereas mineral dust is assumed to be insoluble and to follow FHH adsorption theory. Particles within each mode are modeled as internally mixed and follow a prescribed in-cloud number size distribution following the approach of Karydis et al. (2011) (Table 1).

Other important parameters for CDNC calculations include an effective water vapor uptake coefficient of 0.06 (Fountoukis et al., 2007) and FHH adsorption parameters, $A_{\mathrm{FHH}}=2.25$ and $B_{\mathrm{FHH}}=1.2$ (Kumar et al., 2011a; Karydis et al., 2011). Additionally, the updraft velocities are representative of typical stratocumulus clouds and are constrained using observations, $V=0.3 \mathrm{~ms}^{-1}$ over land, and $V=0.15 \mathrm{~m} \mathrm{~s}^{-1}$ over ocean (Guibert et al., 2003; Meskhidze et al., 2005; Chuang et al., 2000). Karydis et al. (2011) compared the predicted CDNC, based on these parameters, against observational data from continental, polluted marine and clean marine regions around the world. Overall, they found that the model is often in reasonably good agreement with observations.

\subsection{GEOS-Chem}

The GEOS-Chem 3-D global CTM (v9-01-01; http:// geos-chem.org) documented first in Bey et al. (2001) and Park et al. (2004), is driven by the NASA GMAO GEOS5 assimilated meteorological data. The model was executed for December 2006 to December 2008, with the first year considered to be model spin-up. The temporal resolution of GEOS-5 is $6 \mathrm{~h}$ or $3 \mathrm{~h}$ for surface variables and mixing depths; the data are aggregated from $0.5^{\circ}$ by $0.67^{\circ}$ horizontal resolution to $2^{\circ}$ by $2.5^{\circ}$, and in vertical resolution from 72 to
47 hybrid pressure-sigma levels from the surface to $0.01 \mathrm{hPa}$ (Bey et al., 2001).

The model simulates tropospheric ozone- $\mathrm{NO}_{\mathrm{x}}{ }^{-}$ hydrocarbon-aerosol chemistry as described by Zhang et al. (2012). The sulfate-nitrate-ammonium aerosol system interacts with the gas phase according to equilibrium thermodynamics (Park et al., 2004; Pye et al., 2009) calculated with ISORROPIA II (Fountoukis et al., 2007). The rate of in-cloud production of sulfate is in accordance with the liquid water content given by GEOS-5 for each grid cell as recently described by Fisher et al. (2011). Other inorganic aerosol species represented are accumulation and coarse mode sea salt (Alexander et al., 2005) and four classes of dust aerosol (Fairlie et al., 2007). Nitrate and sulfate can accumulate on sea salt aerosol. Organic aerosol (OC) and elemental carbon (EC) are represented as either hydrophobic or hydrophilic; hydrophobic carbonaceous aerosol shift to hydrophilic (1.2 day e-folding time) (Park et al., 2003).

Emissions of aerosol-related species are compiled from a variety of inventories. Anthropogenic emissions of $\mathrm{CO}$, $\mathrm{NO}_{\mathrm{x}}$, and $\mathrm{SO}_{2}$ are defined by the EDGAR 3.2 monthly global inventory for 2000 (Olivier and Berdowski, 2001), which are scaled to modeled years according to economic data (van Donkelaar et al., 2008) or superseded by regional inventories (e.g., US (NEI05), Canada (CAC), Mexico (BRAVO), Europe (EMEP), and East Asia; Streets et al., 2006). Bond et al. (2007) describes the global inventory of anthropogenic emissions of carbonaceous aerosols (BC/OC), which was implemented by Leibensperger et al. (2012). Global shipping emissions are from ICOADS, which were implemented by Lee et al. (2011a). Natural emissions include open biomass burning from GFED2 (van der Werf et al., 2009); biogenic 
soil $\mathrm{NO}_{\mathrm{x}}$ emissions of Yienger and Levy (1995); eruptive and non-eruptive volcanic $\mathrm{SO}_{2}$ emissions developed by T. Diehl (http://aerocom.met.no/data.html) and implemented in GEOS-Chem by Fisher et al. (2011); and lightning $\mathrm{NO}_{\mathrm{x}}$ in accordance with Price and Rind (1992). Estimates from Leibensperger et al. (2012) for GEOS-Chem are representative of the annual global emissions of $\mathrm{SO}_{2}, \mathrm{BC}$, and $\mathrm{POC}$ in this study of $105 \mathrm{Tg} \mathrm{S} \mathrm{yr}^{-1}, 7.3 \mathrm{Tg} \mathrm{C} \mathrm{yr}^{-1}$, and $33 \mathrm{Tg} \mathrm{Cyr}^{-1}$, respectively.

Deposition processes govern the removal of aerosol and related gases. Water-soluble gases and aerosols undergo wet deposition as described by Mari et al. (2000) and Liu et al. (2001), respectively. Recently, corrections were implemented to improve washout for highly soluble gases other than $\mathrm{HNO}_{3}$ (Amos et al., 2012) and to allow washout and rainout in the same grid box (Wang et al., 2004). The resistance-in-series scheme of Wesely (1989), implemented by Wang et al. (1998), describes dry deposition.

Monthly-averaged mass concentrations of aerosols are computed from GEOS-Chem and are given as an input to the cloud droplet formation parameterization. Aerosols are distributed in three modes: sulfate, ammonium, nitrate, organic mass, and black carbon from anthropogenic and biomass burning sources; sulfate, nitrate, and sea salt from marine processes; and mineral dust. The CCN activity of aerosols from the first two modes is assumed to follow Köhler theory whereas mineral dust is assumed to be insoluble and follow FHH adsorption activation theory. Particles within each mode are internally mixed and assumed to follow a prescribed in-cloud number size distribution following Karydis et al. (2011) (Table 1). Other parameters required for CDNC calculations follow those used for the GMI model.

\section{Results and discussion}

\subsection{Overview of model predictions}

The predicted annual mean CDNC at the lowest cloudforming level derived from the aerosol concentration fields of GMI and GEOS-Chem models are shown in Figs. 3a and $4 \mathrm{a}$, respectively. CDNC refers to the number concentration of droplets nucleated in-cloud and represents an upper limit since the parameterization does not account for droplet depletion by collision, coalescence and collection. As expected, higher CDNC concentrations (up to $750 \mathrm{~cm}^{-3}$ ) are predicted over the mid-latitudes of the Northern Hemisphere (i.e., over east Asia, Europe, and Eastern US), which is in accordance with the high CCN concentrations occurring over the industrialized regions. The predicted CDNC based on the GEOSChem aerosol concentration field is higher over East Asia than over Europe or the United States. GMI predicts similar CDNC over these three regions. Given that the years simulated by GEOS-Chem and GMI are 2008 and 1999, respectively, this trend depicts the increase of East Asian emissions during the last decade. Over the continents of the Southern Hemisphere, large CDNC values occur over South America and Africa in regions affected by biomass burning. The predicted CDNC from GEOS-Chem (up to $700 \mathrm{~cm}^{-3}$ ) is higher than the corresponding GMI predictions (up to $600 \mathrm{~cm}^{-3}$ ) over these regions. Over oceans, CDNC is increased up to $200 \mathrm{~cm}^{-3}$ by continental aerosol transported from the subtropical west coasts of Africa and America, and the east coasts of North America and Asia (Minnis et al., 1992; Prospero et al., 1983). Lower CDNCs are predicted over the cleaner remote oceans of the Southern Hemisphere and in the Polar Regions (up to $80 \mathrm{~cm}^{-3}$ ). The lowest concentration predicted by GEOS-Chem $\left(\sim 40 \mathrm{~cm}^{-3}\right)$ is about twofold higher than GMI $\left(\sim 20 \mathrm{~cm}^{-3}\right)$.

The predicted CDNC from GEOS-Chem and GMI are also compared against observational data from continental, polluted marine and clean marine regions around the world, described by Karydis et al. (2011). The summary of this comparison (Fig. 5) shows that over clean marine regions, concentration ranges from $31 \mathrm{~cm}^{-3}\left(49 \mathrm{~cm}^{-3}\right)$ to $161 \mathrm{~cm}^{-3}\left(247 \mathrm{~cm}^{-3}\right)$ (Eastern Pacific) are predicted from GMI (GEOS-Chem), respectively; these agree with observed CDNC values mostly to within $50 \%$ for $57 \%$ (64\%) of the cases, which range from $17 \mathrm{~cm}^{-3}$ to $272 \mathrm{~cm}^{-3}$. The predicted CDNC range increases to $72-520 \mathrm{~cm}^{-3}$ (in GMI) and 70 $498 \mathrm{~cm}^{-3}$ (in GEOS-Chem) over polluted marine regions close to coasts. These are well within the observed values over those regions $\left(61-325 \mathrm{~cm}^{-3}\right)$, as $39 \%$ and $57 \%$ of the GMI and GEOS-Chem predictions, respectively, diverge less than $50 \%$ from the measurements. The predicted CDNC over continental regions ranges between $98 \mathrm{~cm}^{-3}$ and $677 \mathrm{~cm}^{-3}$ in GMI and between $80 \mathrm{~cm}^{-3}$ and $704 \mathrm{~cm}^{-3}$ in GEOS-Chem; observed values range from $56 \mathrm{~cm}^{-3}$ up to $1050 \mathrm{~cm}^{-3}$. A significant fraction ( $40 \%$ and $49 \%$ ) of the CDNC predictions from GMI and GEOS-Chem, respectively, diverge less than $50 \%$ from the available measurements over the continents.

\subsection{Sensitivity of global CDNC distribution to input parameters}

CDNC sensitivity to input parameters (updraft velocity, uptake coefficient, and aerosol concentration) were calculated and for comparison are presented as fully normalized by the value of the input parameter and the predicted CDNC (i.e., $\frac{I}{N_{\mathrm{d}}} \frac{\partial N_{\mathrm{d}}}{\partial I}=\frac{\partial \ln N_{\mathrm{d}}}{\partial \ln I}$, where $I$ is the input parameter considered).

Updraft velocity: Figs. $3 \mathrm{~b}$ and $4 \mathrm{~b}$ depict the global annual average sensitivity distribution of CDNC to updraft velocity, $V$, derived from GMI and GEOS-Chem models, respectively. CDNC exhibits an approximate power law dependence on the updraft velocity, i.e. $N_{\mathrm{d}}=\alpha V^{b}$, with $\alpha$ being positive, and $b$ ranging from 0 to 1 (Morales and Nenes, 2010). Therefore, the CDNC sensitivity to updraft velocity, $\frac{\partial N_{\mathrm{d}}}{\partial V}=\alpha b V^{b-1}$, is higher when $V$ is low since $b-1<0$, and depends on the available $\mathrm{CN}$ and the predicted activation fraction $\left(\frac{\mathrm{CCN}}{\mathrm{CN}}\right)$ as follows. $\frac{\partial N_{\mathrm{d}}}{\partial V}$ can be written as 
(a) GMI-CDNC

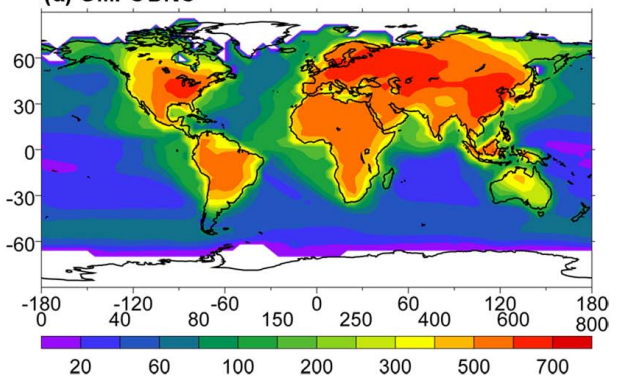

(c) GMI-CDNC Sensitivity to $\alpha_{c}$

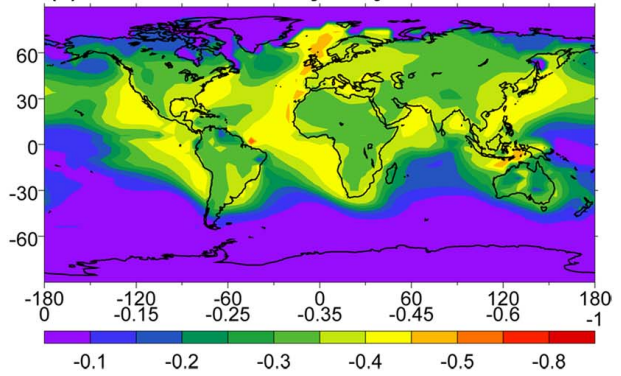

(e) GMI-CDNC Sensitivity to $N_{\alpha-s s}$

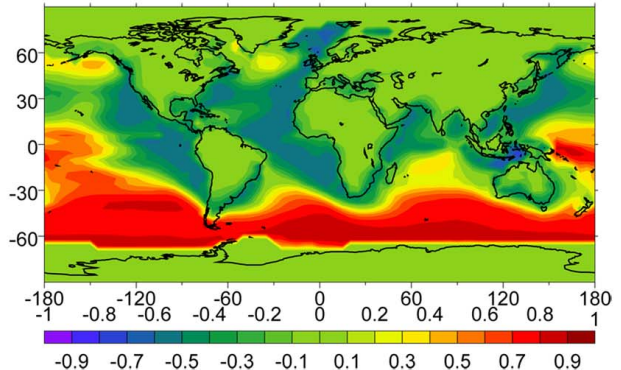

(g) GMI-CDNC Sensitivity to $\boldsymbol{K}_{S S}$

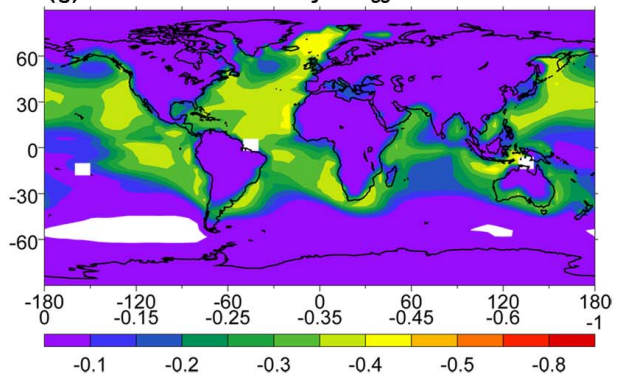

(b) GMI-CDNC Sensitivity to $V$

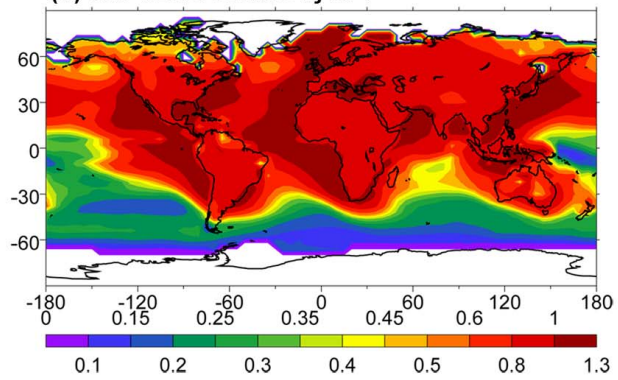

(d) GMI-CDNC Sensitivity to $N_{\alpha-A}$ and $N_{\alpha-B B}$

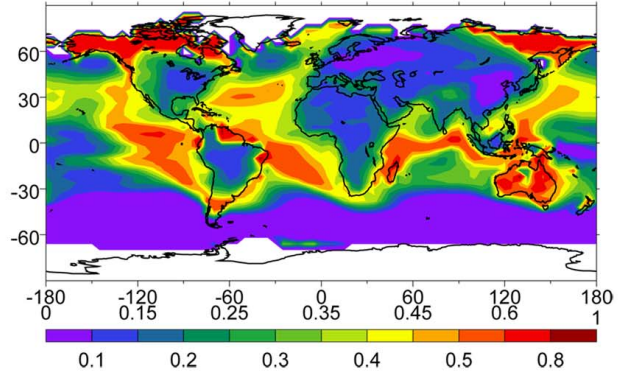

(f) GMI-CDNC Sensitivity to $\kappa_{A}$ and $\kappa_{B B}$

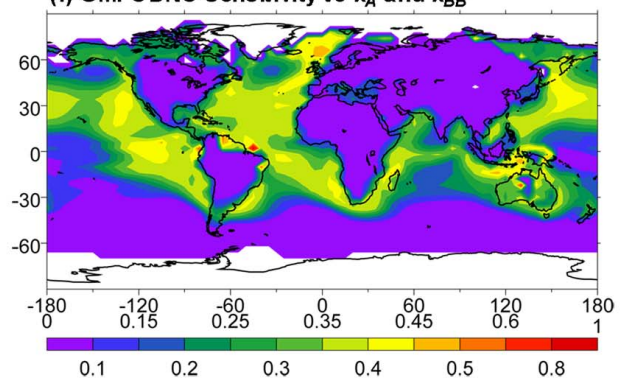

(h) GMI-CDNC Sensitivity to $B_{F H}$

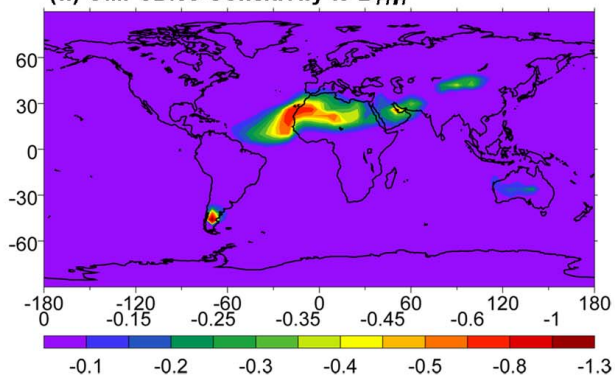

Fig. 3. Predicted annual mean (a) cloud droplet number concentration $\left(\mathrm{cm}^{-3}\right)$, and its sensitivity to (b) updraft velocity $(V)$, (c) uptake coefficient $\left(\alpha_{\mathrm{c}}\right)$, (d) anthropogenic and biomass burning aerosol number concentration $\left(N_{\alpha-\mathrm{A}}+N_{\alpha-\mathrm{BB}}\right)$, (e) sea salt aerosol number concentration $\left(N_{p-\mathrm{SS}}\right)$, (f) anthropogenic and biomass burning aerosol hygroscopicity $\left(\kappa_{\mathrm{A}}+\kappa_{\mathrm{BB}}\right)$, (g) sea salt aerosol hygroscopicity $\left(\kappa_{\mathrm{SS}}\right)$ and (h) $B_{\mathrm{FHH}}$ adsorption parameter derived from the aerosol concentration fields of GMI model for the lowest cloud-forming level.

$\frac{\partial N_{\mathrm{d}}}{\partial \mathrm{CCN}} \frac{\partial \mathrm{CCN}}{\partial s_{\max }} \frac{\partial s_{\max }}{\partial V} ; \frac{\partial N_{\mathrm{d}}}{\partial \mathrm{CCN}}\left(\right.$ at $\left.s_{\max }\right)$ is constant and equal to 1 (Nenes et al., 2001), $\frac{\partial C C N}{\partial s_{\max }}$ is higher in low activation fractions, and $\frac{\partial s_{\max }}{\partial V}$ is higher in low updrafts. In areas where the activation fraction is high (i.e., Southern Oceans), $\frac{\partial C \mathrm{CN}}{\partial s_{\max }}$ is very small, as most of the aerosols are already activated into droplets, so the CDNC sensitivity to updraft velocity is predicted to be as low as 0.2 and 0.4 by GMI and GEOS-Chem, respectively. GEOS-Chem predicts a higher sensitivity over the pristine environments than GMI due to the lower activation fractions of the former over these areas as the initial aerosol loading in GEOS-Chem is higher, which results in a lower $s_{\max }$. When the activation fraction is low (i.e., polluted marine and continental environments), the $\frac{\partial \mathrm{CCN}}{\partial s_{\max }}$ and $\frac{\partial s_{\max }}{\partial V}$ are high, resulting in large CDNC sensitivity to updraft 
(a) GEOS Chem-CDNC

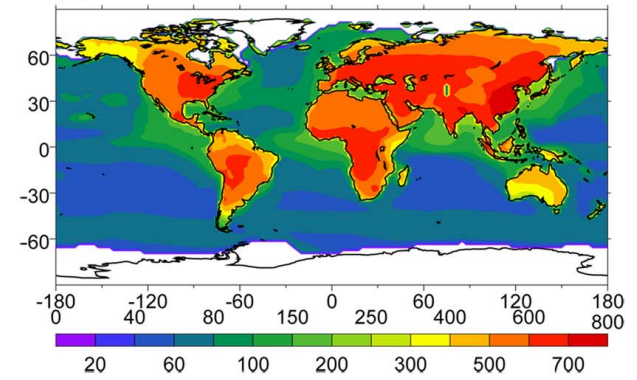

(c) GEOS Chem-CDNC Sensitivity to $\alpha_{c}$

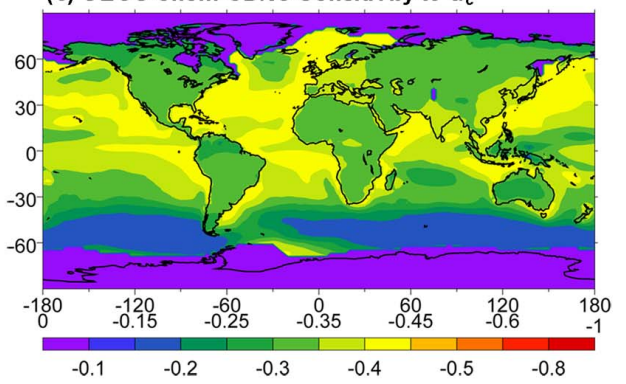

(e) GEOS Chem-CDNC Sensitivity to $N_{\alpha-S S}$

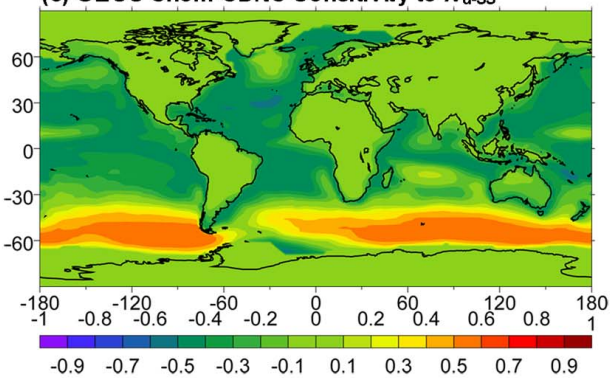

(g) GEOS Chem-CDNC Sensitivity to $\kappa_{S S}$

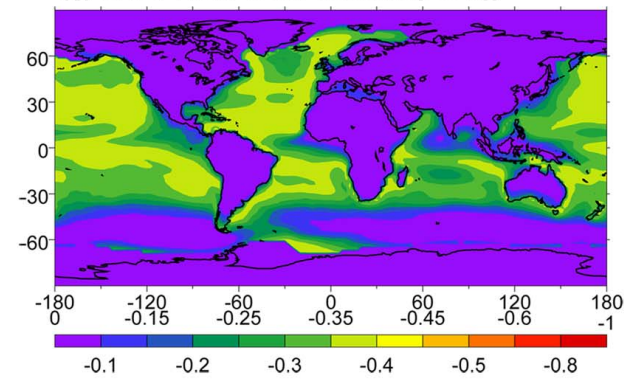

(b) GEOS Chem-CDNC Sensitivity to $V$

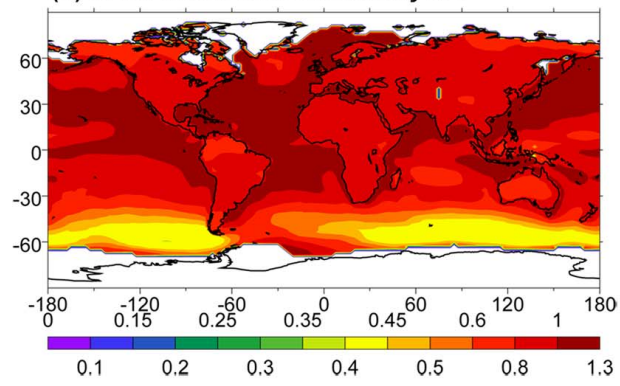

(d) GEOS Chem-CDNC Sensitivity to $N_{\alpha-A}$ and $N_{\alpha-B B}$

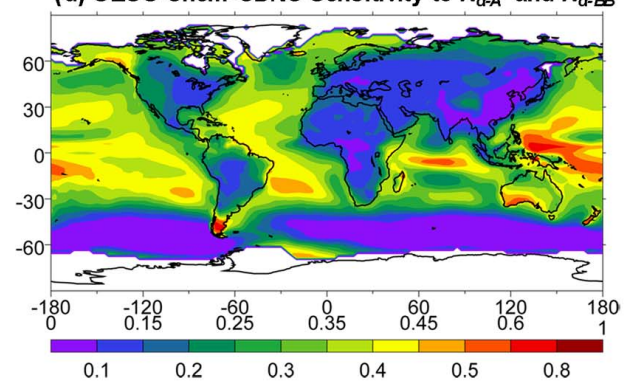

(f) GEOS Chem-CDNC Sensitivity to $\kappa_{A}$ and $\kappa_{B B}$

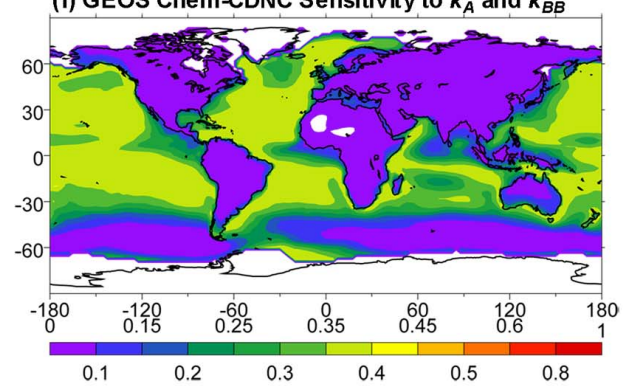

(h) GEOS Chem-CDNC Sensitivity to $B_{F H H}$

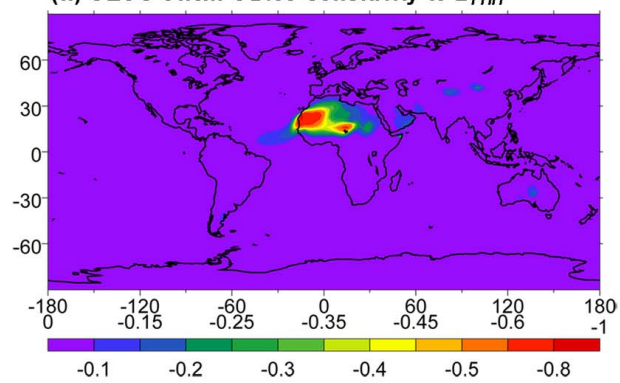

Fig. 4. Predicted annual mean (a) cloud droplet number concentration $\left(\mathrm{cm}^{-3}\right)$, and its sensitivity to (b) updraft velocity $(V)$, (c) uptake coefficient $\left(\alpha_{\mathrm{c}}\right)$, (d) anthropogenic and biomass burning aerosol number concentration $\left(N_{\alpha-\mathrm{A}}+N_{\alpha-\mathrm{BB}}\right)$, (e) sea salt aerosol number concentration $\left(N_{p-\mathrm{SS}}\right)$, (f) anthropogenic and biomass burning aerosol hygroscopicity $\left(\kappa_{\mathrm{A}}+\kappa_{\mathrm{BB}}\right),(\mathrm{g})$ sea salt aerosol hygroscopicity $\left(\kappa_{\mathrm{SS}}\right)$ and (h) $B_{\mathrm{FHH}}$ adsorption parameter derived from the aerosol concentration fields of GEOS-Chem model for the lowest cloud-forming level.

velocity over these areas. Given that the updraft velocity over oceans tends to be lower than over land, the sensitivity of CDNC is larger over the polluted marine areas and especially close to coasts than over the continents with values up to 1.2 and 1.3 over W. Europe by GEOS-Chem and GMI, respectively. Over the continents, the sensitivity is larger over Eastern Asia, Central Europe, and Eastern North America (up to
1) where the activation fraction is predicted to be low (between $1 \%$ and $6 \%$ ).

Uptake coefficient: the sensitivity of CDNC to water uptake coefficient, $\frac{\partial N_{\mathrm{d}}}{\partial \alpha_{\mathrm{c}}}$, is negative and larger over the polluted environments of the Northern Hemisphere (Figs. 3c, $4 c)$. The sensitivity is negative because a higher coefficient increases the water uptake from the aerosols in the 

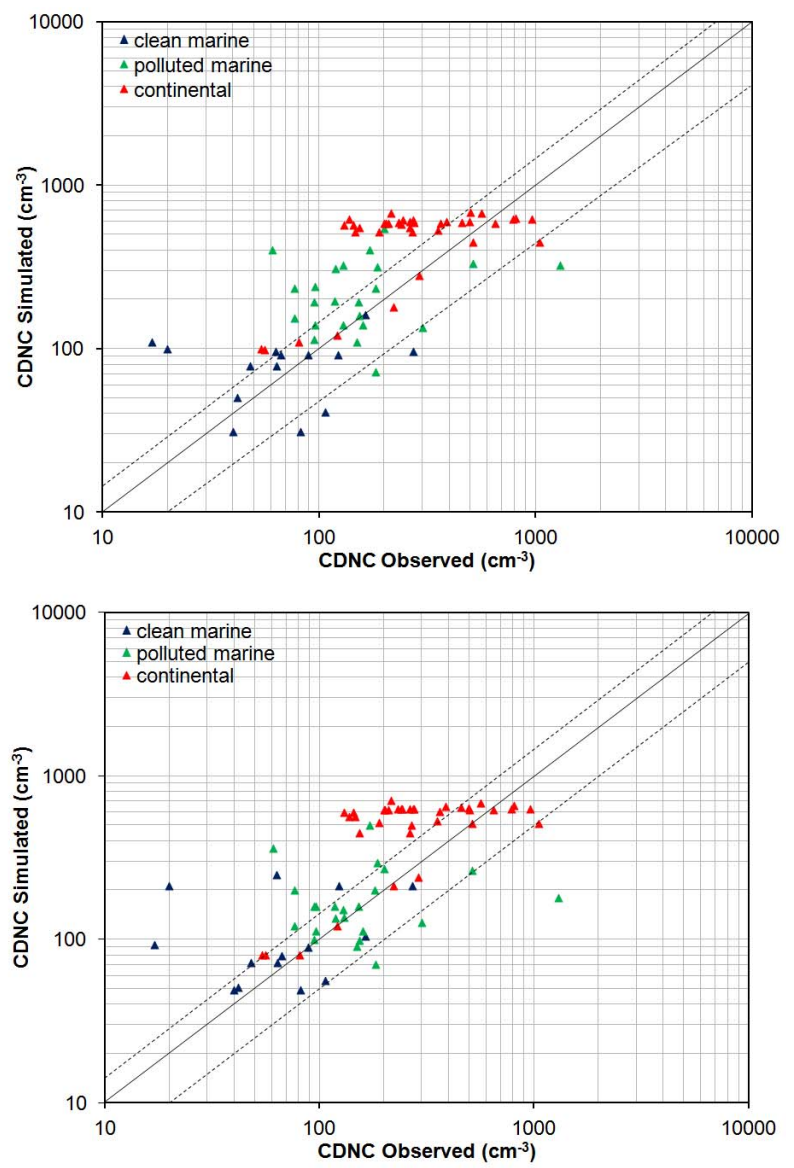

Fig. 5. Comparison of GMI (top panel) and GEOS-Chem (bottom panel) simulated global CDNC against observational data (which are sorted by region). Also shown are the $1: 1$ and $\pm 50 \%$ lines.

initial state of cloud formation, decreasing the maximum supersaturation in clouds and, thus, the predicted CDNC. The largest sensitivity is predicted over the west coasts of Europe and North Africa (up to -0.6 ). $\frac{\partial N_{\mathrm{d}}}{\partial \alpha_{\mathrm{c}}}$ is also large $(\sim-0.4)$ over Eastern Asia, Europe, Eastern US, as well as over the biomass burning areas of South America and Central Africa, due to the low activation fractions. Over more pristine environments, such as the Southern Oceans, uptake coefficient has a lower impact on CDNC, with $\frac{\partial N_{\mathrm{d}}}{\partial \alpha_{\mathrm{c}}} \geq-0.1$ and -0.2 by the GMI and GEOS-Chem models, respectively. Over these environments, the availability of the aerosols is much lower (activation fraction is high) and therefore changes in $\alpha_{\mathrm{c}}$ result in only small changes to the overall water uptake and maximum supersaturation. Sensitivities to updraft velocity and uptake coefficient have similar spatial distribution (Figs. 3b, c and $4 b, c)$ but they are opposite in sign (Fig. 6a). CDNC is predicted to be roughly twofold less sensitive to changes in the uptake coefficient than in the updraft velocity (Fig. 6a). According to Fountoukis and Nenes (2005), $\frac{\partial D_{V}^{\prime}}{\partial \alpha_{c}} \sim-0.5$, where $D_{V}^{\prime}$ is the mass transfer coefficient that accounts for gas-phase non-continuum effects (effective diffusivity) of water vapor onto the droplets. Substituting $D_{V}^{\prime}$ in the $G$ term of Eq. (2) we obtain $V=\frac{\pi \gamma \rho_{\mathrm{w}}}{2 a} D_{V}^{\prime} s_{\max } I\left(0, s_{\max }\right)$ and therefore $\frac{\partial V}{\partial \alpha_{\mathrm{c}}} \sim \frac{\partial D_{V}^{\prime}}{\partial \alpha_{\mathrm{c}}} \frac{\pi \gamma \rho_{\mathrm{w}}}{2 a} s_{\max } I\left(0, s_{\max }\right) \sim-0.5 \frac{\pi \gamma \rho_{w}}{2 a} s_{\max } I\left(0, s_{\max }\right)$. Consequently, changing the uptake coefficient is equivalent to a negatively proportional change of the updraft velocity, and explains the strong anticorrelation between $\frac{\partial N_{\mathrm{d}}}{\partial \alpha_{\mathrm{c}}}$ and $\mathrm{CCN}$.

Aerosol concentration: the sensitivity of CDNC to anthropogenic and biomass burning aerosol concentrations, $\frac{\partial N_{\mathrm{d}}}{\partial\left(N_{\alpha-\mathrm{A}}+N_{\alpha-\mathrm{BB}}\right)}$, which include sulfate, OC, and BC (for GMI), and, sulfate, nitrate, ammonium, OC, and BC (for GEOS-Chem) depends on the environmental conditions (Figs. 3d and 4d). In polluted areas, an increase in aerosol concentration will lead to a small increase in CDNC as both the $s_{\max }$ and the droplet activation fraction are low. On the other hand, clean areas are characterized by high $s_{\max }$ and droplet activation fractions, resulting in large CDNC increases when aerosol concentration is increased. Consequently, both GMI and GEOS-Chem predict a moderate influence (up to 0.2) of aerosol concentration on CDNC over East Asia, Europe, and Eastern Northern America, as well as over the biomass burning areas of South America and South Africa; the lowest values are predicted over East Asia (less than 0.1$)$. The moderate value of $\frac{\partial N_{\mathrm{d}}}{\partial\left(N_{\alpha-\mathrm{A}}+N_{\alpha-\mathrm{BB}}\right)}$ computed is in accordance with Pöschl et al. (2010), where the formation of cloud droplets in the polluted environments of the Amazon Basin, influenced by intense biomass burning, depended primarily on the updraft velocity and not on aerosol number. On the other hand, the sensitivity of CDNC to aerosol concentration is moderate along the polluted coasts $\left(\frac{\partial N_{\mathrm{d}}}{\partial\left(N_{\alpha-\mathrm{A}}+N_{\alpha-\mathrm{BB}}\right)} \sim\right.$ $0.4)$ and increases as we move to more pristine environments such as the tropical Pacific and Atlantic Oceans (up to 0.7$)$. The $\frac{\partial N_{\mathrm{d}}}{\partial\left(N_{\alpha-\mathrm{A}}+N_{\alpha-\mathrm{BB}}\right)}$ over the southern oceans is not large given that CDNC is most sensitive to sea salt, the main aerosol component in the area. Sotiropoulou et al. (2007) also presented the global spatial relative sensitivity of CDNC to $\mathrm{CCN}$ number, and found that sensitivity increased from polluted $(\sim 0.7)$ to more pristine $(\sim 0.9)$ environments (a behavior consistent with the results discussed above but somewhat greater in magnitude).

The sensitivity of CDNC to sea salt aerosols, $\frac{\partial N_{\mathrm{d}}}{\partial N_{\alpha-S S}}$, over the Southern Oceans is predicted to be up to 1 and 0.6 by the GMI and GEOS-Chem applications, respectively (Figs. 3e and 4e). This twofold difference can be attributed to the lower CDNC concentrations predicted over this area by the GMI model compared to GEOS-Chem (Figs. 3a, 4c). On the other hand, over the Northern Hemisphere oceans, sea salt aerosols co-exist with anthropogenic and biomass burning aerosols. In polluted environments, the coarse sea salt aerosols compete with the submicron anthropogenic and biomass burning aerosols for water vapor. Given that coarse sea salt activates at much lower $s_{\mathrm{c}}$ than the other aerosols, its addition may 

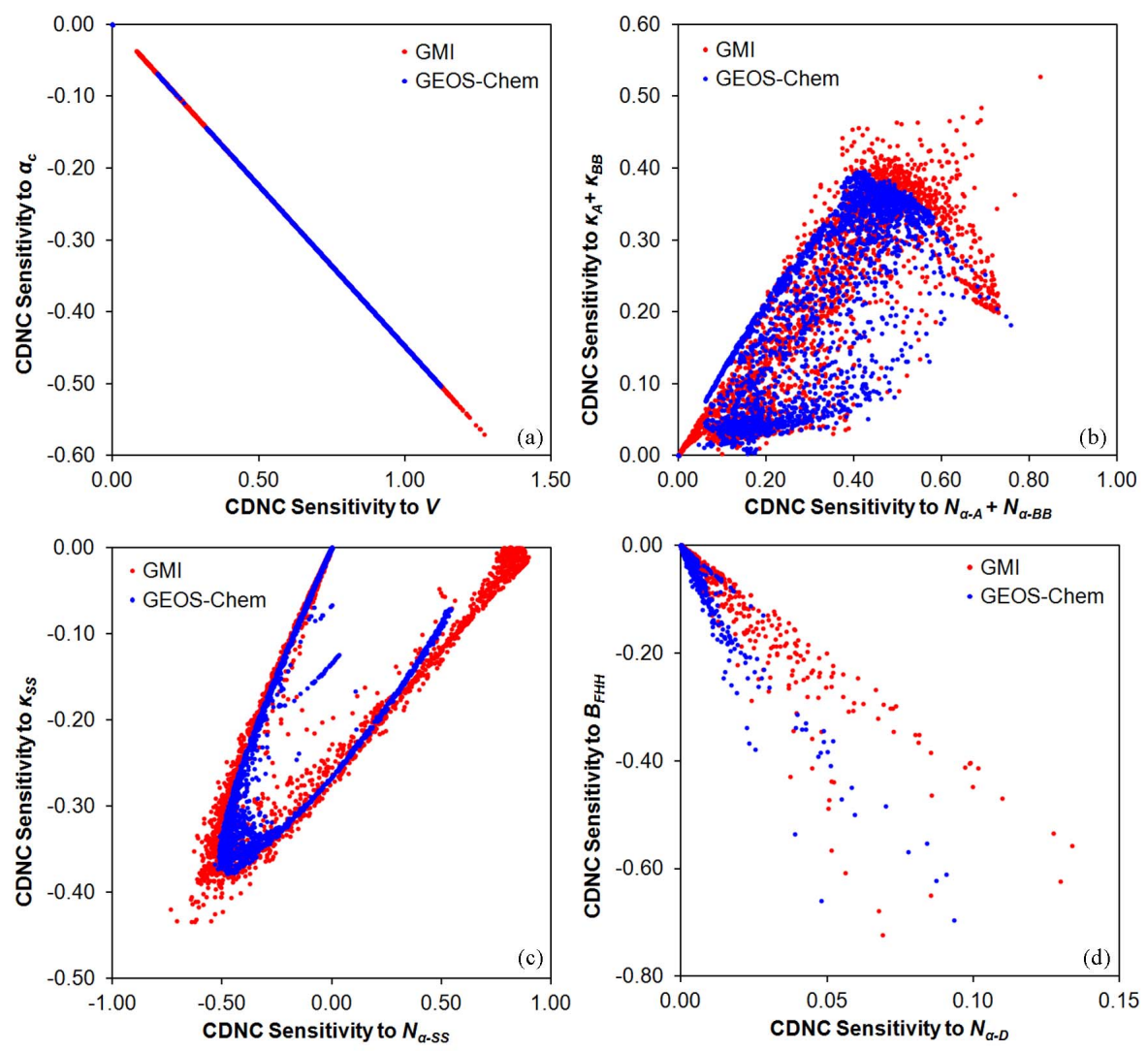

Fig. 6. Comparison between the predicted annual mean cloud droplet number concentration sensitivity to (a) updraft velocity ( $V$ ) and uptake coefficient $\left(\alpha_{\mathrm{c}}\right)$, (b) anthropogenic and biomass burning aerosol number concentration $\left(N_{\alpha-\mathrm{A}}+N_{\alpha-\mathrm{BB}}\right)$ and hygroscopicity $\left(\kappa_{\mathrm{A}}+\kappa_{\mathrm{BB}}\right)$, (c) sea salt aerosol number concentration $\left(N_{\alpha-\mathrm{SS}}\right)$ and hygroscopicity $\left(\kappa_{\mathrm{SS}}\right)$ and (d) dust aerosol number concentration $\left(N_{\alpha-\mathrm{D}}\right)$ and $B_{\mathrm{FHH}}$ adsorption parameter, derived from the aerosol concentration fields of GEOS-Chem and GMI models for the lowest cloud-forming level.

substantially increase the aerosol surface area at the point of $s_{\max }$, lowering the available water vapor, $s_{\max }$ and CDNC (Ghan et al., 1998; Barahona et al., 2010). Because of this, the sensitivity of CDNC to sea salt aerosol concentration over polluted marine environments is negative (up to -0.6) (Figs. 3e and 4e). On the other hand, sensitivity of CDNC to submicron sea salt aerosol (i.e., assuming that coarse sea salt does not vary) is positive, similar to the effect of the anthropogenic and biomass burning aerosols on CDNC described above.

Aerosol hygroscopicity: Figs. 3f and $4 \mathrm{f}$ depicts the sensitivity of CDNC to the bulk hygroscopicity of anthropogenic and biomass burning aerosols. Over areas with high aerosol load, the $s_{\max }$ and the droplet activation fraction are very low; thus, increasing the hygroscopicity of the aerosols will have a very small impact on CDNC (less than 0.1) as the tendency to increase the activation fraction will be compensated by a decrease in $s_{\max }$ due to the increasing competition for water vapor. Ervens et al. (2010) also reported that over six different continental locations, at $V \sim 0.3 \mathrm{~m} \mathrm{~s}^{-1}$, the sensitivity of CDNC to particle composition $(\kappa)$ was about 0.1 to 0.2 . This suggests that over these regions, a simple assumption of the aerosol composition and mixing state is adequate for an accurate prediction of CDNC. Over moderately polluted areas (i.e., over the north Atlantic and Pacific Oceans) the droplet activation fraction is moderately high $(\sim 15 \%)$. Increasing the hygroscopicity of the aerosols will lead to a notable increase in the droplet activation fraction without a compensating decrease on $s_{\max }$ as the competition for water (because of decreased availability of $\mathrm{CCN}$ ) is less intense. GMI and GEOS-Chem predict that over Atlantic and Pacific Oceans, the CDNC sensitivity to anthropogenic and biomass burning aerosol hygroscopicity is up to 0.4 (Figs. 3f, 4 f). $\frac{\partial N_{\mathrm{d}}}{\partial V} \sim 1$ in this region (Figs. 3b, 4b) which is consistent with Rissman et al. (2004), who also found that the sensitivity ratio $\frac{\partial N_{\mathrm{d}} / \partial \kappa}{\partial N_{\mathrm{d}} / \partial V}$ in marine stratocumulus is up to 0.4 . Moreover, Moore et al. (2011), based on data from the Alaskan Arctic during the ARCPAC project, found that the sensitivity of CCN to $\kappa$ at $0.1 \%$ supersaturation (similar to $s_{\max }$ predicted in this study over Alaska) is up to 0.3, which is in general agreement to the $\frac{\partial N_{\mathrm{d}}}{\partial \kappa}$ predicted by GEOS-Chem and GMI over the same area (up to 0.15 and 0.3 , respectively). Moore et al. (2012) used CCN data sampled at California during the CalNex project in order to investigate its sensitivity to $\kappa$. At 
$0.06 \%$ supersaturation (similar to $s_{\max }$ predicted in this study over California) the $\frac{\partial N_{\mathrm{d}}}{\partial \kappa}$ was calculated up to 0.15 , compared to 0.1 and 0.15 predicted by GEOS-Chem and GMI, respectively, over the same area. Overall, CDNC is predicted to be less sensitive (on average by twofold) to changes in the hygroscopicity of the aerosols than in their concentration in most of the cases (Fig. 6b, c). This agrees well with Ervens et al. (2007) who found that the measured aerosol size distribution is always of primary importance for CCN closure, while the relative importance of the aerosol composition is low. However, we show here that the sensitivities to compositional changes are regionally significant especially for the arctic and remote oceans.

The hydrophilicity of dust aerosols is expressed by the $A_{\mathrm{FHH}}$ and $B_{\mathrm{FHH}}$ adsorption parameters with the latter being of most importance (Kumar et al., 2011a; Karydis et al., 2011). Smaller values of $B_{\mathrm{FHH}}$ correspond to more hydrophilic dust. Figures $3 \mathrm{~h}$ and $4 \mathrm{~h}$ depict the sensitivity of CDNC to the $B_{\mathrm{FHH}}$ adsorption parameter. Both GMI and GEOS-Chem applications predict a large sensitivity over the Sahara desert and across the tropical Atlantic Ocean (up to -0.8 ). Over the other arid areas of the world, GMI predicts much higher sensitivity than GEOS-Chem. In particular, GMI predicts sensitivities as large as -1.3 over Patagonian desert, -0.5 over the Arabian Peninsula, -0.4 over the Gobi desert, and -0.3 over Australia; whereas GEOSChem predicts $\frac{\partial N_{\mathrm{d}}}{\partial B_{\mathrm{FHH}}} \sim-0.2$ over all these areas. The discrepancy between both models is attributed to the higher anthropogenic aerosol concentrations predicted by GEOSChem over deserts due to the more efficient transport of pollutants. The sensitivity of droplet number to dust hydrophylicity depends on the relative contribution of dust and anthropogenic aerosols to total aerosol number concentration as higher fractions of anthropogenic aerosols reduces the impact of dust hydrophilicity on total droplet number. The sensitivity of CDNC to $A_{\mathrm{FHH}}$ adsorption parameter is up to 0.1 over desert areas. Finally, in contrast to other aerosol types, the hydrophilicity of dust aerosols (expressed through the $B_{\mathrm{FHH}}$ parameter) has a significantly greater relative impact on CDNC than the dust aerosol concentration (Fig. 6d). In particular, the sensitivity of CDNC to $B_{\mathrm{FHH}}$ parameter is 5.5 and 8 times higher than to dust aerosol concentration over land and ocean, respectively.

\section{Conclusions}

This study introduces a novel approach to comprehensively and efficiently quantify the sensitivity of 3-D CDNC distribution to updraft velocity, aerosol uptake coefficient, aerosol number and hygroscopicity. Sensitivities are calculated by developing the adjoint of an aerosol-droplet parameterization. The parameterization used in this study considers cloud droplet formation within an ascending air parcel containing an external mixture of soluble particles and insoluble wet- table particles. Sensitivity calculations are demonstrated using the GMI and GEOS-Chem 3-D global CTMs.

CDNC is more sensitive to updraft velocity and uptake coefficient over land and polluted marine environments and less sensitive to those parameters over pristine environments (i.e., over the Southern Ocean). In contrast to updraft velocity, the impact of the uptake coefficient to CDNC is negative. Moreover, CDNC is predicted to be less sensitive to changes in the uptake coefficient than in the updraft velocity although the two sensitivities follow the same functional form. CDNC is less sensitive to aerosol concentration and hygroscopicity over land than over oceans. Over the oceans of the Northern Hemisphere, anthropogenic and biomass burning aerosols increase CDNC while coarse sea salt aerosol can reduce CDNC. Over the Southern Ocean, CDNC is almost always positively correlated to sea salt, as the competition for water vapor during droplet formation is not significant. Overall, CDNC is predicted to be less sensitive to changes in the hygroscopicity of the aerosols than in their concentration, although there are regions and times where they result in comparable sensitivities. Mineral dust is considered an exception as its hydrophilicity (expressed through the $B_{\mathrm{FHH}}$ parameter) has a more significant relative impact on CDNC than its concentration.

Adjoint sensitivity analysis is a powerful technique that can quantify the factors that govern global cloud droplet formation by unraveling the relative importance of dynamical and aerosol factors required for its calculation. Immediate applications include a comprehensive understanding of the diversity of indirect forcing estimates across different modeling frameworks; quantifying the influence of spatial, sectoral, and seasonal varying emissions on CDNC; and assimilation of remote sensing products (e.g., Saide et al., 2012). The work presented here can be extended to other processes, providing unprecedented understanding of droplet formation in complex and highly coupled climate modeling frameworks.

Acknowledgements. We would like to acknowledge support from NASA ACMAP contract NNX08AK50G, NOAA and Georgia Power chair funds. S. L. C. gratefully acknowledges the NSF GRF and NASA ESSF.

Edited by: G. McFiggans

\section{References}

Abdul-Razzak, H. and Ghan, S. J.: A parameterization of aerosol activation 2. Multiple aerosol types, J. Geophys. Res., 105, 68376844, doi:10.1029/1999JD901161, 2000.

Alexander, B., Park, R. J., Jacob, D. J., Li, Q. B., Yantosca, R. M., Savarino, J., Lee, C. C. W., and Thiemens, M. H.: Sulfate formation in sea-salt aerosols: constraints from oxygen isotopes, J. Geophys. Res., 110, D10307, doi:10.1029/2004jd005659, 2005.

D'Almeida, G. A.: On the variability of desert aerosol radiative characteristics, J. Geophys. Res., 92, 3017-3026, 1987. 
Alterskjær, K., Kristjénsson, J. E., and Seland, Ø.: Sensitivity to deliberate sea salt seeding of marine clouds - observations and model simulations, Atmos. Chem. Phys., 12, 2795-2807, doi:10.5194/acp-12-2795-2012, 2012.

Amos, H. M., Jacob, D. J., Holmes, C. D., Fisher, J. A., Wang, Q., Yantosca, R. M., Corbitt, E. S., Galarneau, E., Rutter, A. P., Gustin, M. S., Steffen, A., Schauer, J. J., Graydon, J. A., Louis, V. L. St., Talbot, R. W., Edgerton, E. S., Zhang, Y., and Sunderland, E. M.: Gas-particle partitioning of atmospheric $\mathrm{Hg}(\mathrm{II})$ and its effect on global mercury deposition, Atmos. Chem. Phys., 12, 591-603, doi:10.5194/acp-12-591-2012, 2012.

Anderson, B. E., Grant, W. B., Gregory, G. L., Browell, E. V., Collins, J. E., Sachse, G. W., Bagwell, D. R., Hudgins, C. H., Blake, B. R., and Blake, N. J.: Aerosols from biomass burning over the tropical South Atlantic region: distributions and impacts, J. Geophys. Res., 101, 24117-24137, doi:10.1029/96JD00717, 1996.

Anttila, T. and Kerminen, V.-M.: On the contribution of Aitken mode particles to cloud droplet populations at continental background areas - a parametric sensitivity study, Atmos. Chem. Phys., 7, 4625-4637, doi:10.5194/acp-7-4625-2007, 2007.

Barahona, D. and Nenes, A.: Parameterization of cloud droplet formation in large-scale models: including effects of entrainment, J. Geophys. Res., 112, D16206, doi:10.1029/2007JD008473, 2007.

Barahona, D., West, R. E. L., Stier, P., Romakkaniemi, S., Kokkola, H., and Nenes, A.: Comprehensively accounting for the effect of giant $\mathrm{CCN}$ in cloud activation parameterizations, Atmos. Chem. Phys., 10, 2467-2473, doi:10.5194/acp-10-2467-2010, 2010.

Barahona, D., Sotiropoulou, R. E. P., and Nenes, A.: Global distribution of cloud droplet number concentration, autoconversion rate and aerosol indirect effect under diabatic droplet activation, J. Geophy. Res., 116, D09203, doi:10.1029/2010JD015274, 2011.

Bartholomew-Biggs, M.: Using Forward Accumulation for Automatic Differentiation of Implicitly-Defined Functions, Computational Optimization and Applications, 9, 65-84, 1998.

Bey, I., Jacob, D. J., Yantosca, R. M., Logan, J. A., Field, B. D., Fiore, A. M., Li, Q. B., Liu, H. G. Y., Mickley, L. J., and Schultz, M. G.: Global modeling of tropospheric chemistry with assimilated meteorology: model description and evaluation, J. Geophys. Res., 106, 23073-23095, doi:10.1029/2001jd000807, 2001.

Bond, T. C., Bhardwaj, E., Dong, R., Jogani, R., Jung, S. K., Roden, C., Streets, D. G., and Trautmann, N. M.: Historical emissions of black and organic carbon aerosol from energy-related combustion, 1850-2000, Global Biogeochem. Cy., 21, GB2018, doi:10.1029/2006gb002840, 2007.

Boucher, O. and Lohmann, U.: The sulfate-CCN-cloud albedo effect - a sensitivity study with 2 general-circulation models, Tellus B, 47, 281-300, doi:10.1034/j.1600-0889.47.issue3.1.x, 1995.

Capps, S. L., Henze, D. K., Hakami, A., Russell, A. G., and Nenes, A.: ANISORROPIA: the adjoint of the aerosol thermodynamic model ISORROPIA, Atmos. Chem. Phys., 12, 527-543, doi:10.5194/acp-12-527-2012, 2012.

Chuang, C. C., Penner, J. E., Taylor, K. E., Grossman, A. S., and Walton, J. J.: An assessment of the radiative effects of anthropogenic sulfate, J. Geophys. Res., 102, 3761-3778, 1997.
Chuang, P. Y., Collins, D. R., Pawlowska, H., Snider, J. R., Jonsson, H. H., Brenguier, J. L., Flagan, R. C., and Seinfeld, J. H.: $\mathrm{CCN}$ measurements during ACE-2 and their relationship to cloud microphysical properties, Tellus B, 52, 843-867, 2000.

Considine, D. B., Bergmann, D. J., and Liu, H.: Sensitivity of Global Modeling Initiative chemistry and transport model simulations of radon-222 and lead-210 to input meteorological data, Atmos. Chem. Phys., 5, 3389-3406, doi:10.5194/acp-5-33892005, 2005.

Ervens, B., Cubison, M., Andrews, E., Feingold, G., Ogren, J. A., Jimenez, J. L., DeCarlo, P., and Nenes, A.: Prediction of cloud condensation nucleus number concentration using measurements of aerosol size distributions and composition and light scattering enhancement due to humidity, J. Geophys. Res., 112, D10S32, doi:10.1029/2006jd007426, 2007.

Ervens, B., Cubison, M. J., Andrews, E., Feingold, G., Ogren, J. A., Jimenez, J. L., Quinn, P. K., Bates, T. S., Wang, J., Zhang, Q., Coe, H., Flynn, M., and Allan, J. D.: CCN predictions using simplified assumptions of organic aerosol composition and mixing state: a synthesis from six different locations, Atmos. Chem. Phys., 10, 4795-4807, doi:10.5194/acp-10-4795-2010, 2010.

Fairlie, T. D., Jacob, D. J., and Park, R. J.: The impact of transpacific transport of mineral dust in the United States, Atmos. Environ., 41, 1251-1266, doi:10.1016/j.atmosenv.2006.09.048, 2007.

Fisher, J. A., Jacob, D. J., Wang, Q. Q., Bahreini, R., Carouge, C. C., Cubison, M. J., Dibb, J. E., Diehl, T., Jimenez, J. L., Leibensperger, E. M., Lu, Z. F., Meinders, M. B. J., Pye, H. O. T., Quinn, P. K., Sharma, S., Streets, D. G., van Donkelaar, A., and Yantosca, R. M.: Sources, distribution, and acidity of sulfateammonium aerosol in the Arctic in winter-spring, Atmos. Environ., 45, 7301-7318, doi:10.1016/j.atmosenv.2011.08.030, 2011.

Fountoukis, C. and Nenes, A.: Continued development of a cloud droplet formation parameterization for global climate models, J. Geophys. Res., 110, D11212, doi:10.1029/2004jd005591, 2005.

Fountoukis, C., Nenes, A., Meskhidze, N., Bahreini, R., Conant, W. C., Jonsson, H., Murphy, S., Sorooshian, A., Varutbangkul, V., Brechtel, F., Flagan, R. C., and Seinfeld, J. H.: Aerosol-cloud drop concentration closure for clouds sampled during the International Consortium for Atmospheric Research on Transport and Transformation 2004 campaign, J. Geophys. Res., 112, D10S30, doi:10.1029/2006jd007272, 2007.

Ghan, S. J., Guzman, G., and Abdul-Razzak, H.: Competition between sea salt and sulfate particles as cloud condensation nuclei, J. Atmos. Sci., 55, 3340-3347, 1998.

Ghil, M. and Malanotterizzoli, P.: Data assimilation in meteorology and oceanography, Adv. Geophys., 33, 141-266, doi:10.1016/s0065-2687(08)60442-2, 1991.

Giering, R.: Tangent linear and adjoint biogeochemical models, in: Inverse Methods in Global Biogeochemical Cycles, edited by: Kasibhatla, P., Heimann, M., Rayner, P., Mahowald, N., Prinn, R. G., and Hartley, D. E., Geophysical Monograph Series, American Geophysical Union, Washington, 33-48, 2000.

Guibert, S., Snider, J. R., and Brenguier, J. L.: Aerosol activation in marine stratocumulus clouds: 1 . measurement validation for a closure study, J. Geophys. Res., 108, 8628, doi:10.1029/2002JD002678, 2003.

Haerter, J. O., Roeckner, E., Tomassini, L., and von Storch, J. S.: Parametric uncertainty effects on aerosol radiative forcing, Geophys. Res. Lett., 36, L15707, doi:10.1029/2009g1039050, 2009. 
Hakami, A., Henze, D. K., Seinfeld, J. H., Chai, T., Tang, Y., Carmichael, G. R., and Sandu, A.: Adjoint inverse modeling of black carbon during the Asian Pacific Regional Aerosol Characterization Experiment, J. Geophys. Res., 110, D14301, doi:10.1029/2004jd005671, 2005.

Hall, M. C. G.: Application of adjoint sensitivity theory to an atmospheric general-circulation model, J. Atmos. Sci., 43, 2644 2651, 1986.

Hascoët, L. and Pascual, V.: TAPENADE 2.1 user's guide (No. 0300), Sophia Antipolis Cedex: INRIA Sophia Antipolis, 2004.

Henze, D. K., Seinfeld, J. H., and Shindell, D. T.: Inverse modeling and mapping US air quality influences of inorganic $\mathrm{PM}_{2.5}$ precursor emissions using the adjoint of GEOS-Chem, Atmos. Chem. Phys., 9, 5877-5903, doi:10.5194/acp-9-5877-2009, 2009.

Karydis, V. A., Kumar, P., Barahona, D., Sokolik, I. N., and Nenes, A.: On the effect of dust particles on global cloud condensation nuclei and cloud droplet number, J. Geophys. Res., 116, D23204, doi:10.1029/2011jd016283, 2011.

Kopacz, M., Mauzerall, D. L., Wang, J., Leibensperger, E. M., Henze, D. K., and Singh, K.: Origin and radiative forcing of black carbon transported to the Himalayas and Tibetan Plateau, Atmos. Chem. Phys., 11, 2837-2852, doi:10.5194/acp-11-28372011, 2011.

Korhonen, H., Carslaw, K. S., and Romakkaniemi, S.: Enhancement of marine cloud albedo via controlled sea spray injections: a global model study of the influence of emission rates, microphysics and transport, Atmos. Chem. Phys., 10, 4133-4143, doi:10.5194/acp-10-4133-2010, 2010.

Kumar, P., Sokolik, I. N., and Nenes, A.: Parameterization of cloud droplet formation for global and regional models: including adsorption activation from insoluble CCN, Atmos. Chem. Phys., 9, 2517-2532, doi:10.5194/acp-9-2517-2009, 2009.

Kumar, P., Sokolik, I. N., and Nenes, A.: Measurements of cloud condensation nuclei activity and droplet activation kinetics of fresh unprocessed regional dust samples and minerals, Atmos. Chem. Phys., 11, 3527-3541, doi:10.5194/acp-11-3527-2011, 2011a.

Kumar, P., Sokolik, I. N., and Nenes, A.: Cloud condensation nuclei activity and droplet activation kinetics of wet processed regional dust samples and minerals, Atmos. Chem. Phys., 11, 8661-8676, doi:10.5194/acp-11-8661-2011, 2011b.

Lance, S., Nenes, A., and Rissman, T. A.: Chemical and dynamical effects on cloud droplet number: Implications for estimates of the aerosol indirect effect, J. Geophys. Res., 109, D22208, doi:10.1029/2004jd004596, 2004.

Le Dimet, F. X. and Talagrand, O.: Variational algorithms for analysis and assimilation of meteorological observations: theoretical aspects, Tellus B, 38, 97-110, 1986.

Lee, C., Martin, R. V., van Donkelaar, A., Lee, H., Dickerson, R. R., Hains, J. C., Krotkov, N., Richter, A., Vinnikov, K., and Schwab, J. J.: $\mathrm{SO}_{2}$ emissions and lifetimes: estimates from inverse modeling using in situ and global, space-based (SCIAMACHY and OMI) observations, J. Geophys. Res., 116, D06304, doi:10.1029/2010jd014758, 2011a.

Lee, L. A., Carslaw, K. S., Pringle, K. J., Mann, G. W., and Spracklen, D. V.: Emulation of a complex global aerosol model to quantify sensitivity to uncertain parameters, Atmos. Chem. Phys., 11, 12253-12273, doi:10.5194/acp-11-12253-
2011, 2011b

Leibensperger, E. M., Mickley, L. J., Jacob, D. J., Chen, W.-T., Seinfeld, J. H., Nenes, A., Adams, P. J., Streets, D. G., Kumar, N., and Rind, D.: Climatic effects of 1950-2050 changes in US anthropogenic aerosols - Part 1: Aerosol trends and radiative forcing, Atmos. Chem. Phys., 12, 3333-3348, doi:10.5194/acp-12-33332012, 2012.

Lions, J. L.: Optimal control of systems governed by partial differential equations, Springer, Berlin, Germany, 1971.

Liu, H. Y., Jacob, D. J., Bey, I., and Yantosca, R. M.: Constraints from $\mathrm{Pb}-210$ and $\mathrm{Be}-7$ on wet deposition and transport in a global three-dimensional chemical tracer model driven by assimilated meteorological fields, J. Geophys. Res., 106, 1210912128, doi:10.1029/2000jd900839, 2001.

Liu, X. H., Penner, J. E., and Herzog, M.: Global modeling of aerosol dynamics: model description, evaluation, and interactions between sulfate and nonsulfate aerosols, J. Geophys. Res., 110, D18206, doi:10.1029/2004jd005674, 2005.

Liu, X. H. and Wang, J. A.: How important is organic aerosol hygroscopicity to aerosol indirect forcing?, Environ. Res. Lett., 5, 044010, doi:10.1088/1748-9326/5/4/044010, 2010.

Mari, C., Jacob, D. J., and Bechtold, P.: Transport and scavenging of soluble gases in a deep convective cloud, J. Geophys. Res., 105, 22255-22267, doi:10.1029/2000jd900211, 2000.

Martien, P. T. and Harley, R. A.: Adjoint sensitivity analysis for a three-dimensional photochemical model: implementation and method comparison, Environ. Sci. Technol., 40, 2663-2670, doi:10.1021/es0510257, 2006.

Menut, L., Vautard, R., Beekmann, M., and Honore, C.: Sensitivity of photochemical pollution using the adjoint of a simplified chemistry-transport model, J. Geophys. Res., 105, 15379-15402, doi:10.1029/1999jd900953, 2000.

Meskhidze, N., Nenes, A., Conant, W. C., and Seinfeld, J. H.: Evaluation of a new cloud droplet activation parameterization with in situ data from CRYSTAL-FACE and CSTRIPE, J. Geophys. Res., 110, D16202, doi:10.1029/2004jd005703, 2005.

Minnis, P., Heck, P. W., Young, D. F., Fairall, C. W., and Snider, J. B.: Stratocumulus cloud properties derived from simultaneous satellite and island-based instrumentation during fire, J. Appl. Meteorol., 31, 317-339, 1992.

Moore, R. H., Bahreini, R., Brock, C. A., Froyd, K. D., Cozic, J., Holloway, J. S., Middlebrook, A. M., Murphy, D. M., and Nenes, A.: Hygroscopicity and composition of Alaskan Arctic CCN during April 2008, Atmos. Chem. Phys., 11, 11807-11825, doi:10.5194/acp-11-11807-2011, 2011.

Moore, R. H., Cerully, K., Bahreini, R., Brock, C. A., Middlebrook, A. M., and Nenes, A.: Hygroscopicity and composition of California CCN during summer 2010, J. Geophys. Res., 117, D00V12, doi:10.1029/2011JD017352, 2012.

Morales, R. and Nenes, A.: Characteristic updrafts for computing distribution-averaged cloud droplet number and stratocumulus cloud properties, J. Geophys. Res., 115, D18220, doi:10.1029/2009jd013233, 2010.

Morrison, H. and Gettelman, A.: A new two-moment bulk stratiform cloud microphysics scheme in the community atmosphere model, version 3 (CAM3). Part I: description and numerical tests, J. Climate, 21, 3642-3659, doi:10.1175/2008jcli2105.1, 2008 . 
Nenes, A. and Seinfeld, J. H.: Parameterization of cloud droplet formation in global climate models, J. Geophys. Res., 108, 4415, doi:10.1029/2002jd002911, 2003.

Nenes, A., Ghan, S., Abdul-Razzak, H., Chuang, P. Y., and Seinfeld, J. H.: Kinetic limitations on cloud droplet formation and impact on cloud albedo, Tellus B, 53, 133-149, doi:10.1034/j.16000889.2001.d01-12.x, 2001.

Olivier, J. G. J. and Berdowski, J. J. M.: Global emissions sources and sinks, in: The Climate System, A. A. Balkema Publishers/Swets \& Zeitlinger Publishers, Lisse, The Netherlands, 3378, 2001.

Park, R. J., Jacob, D. J., Chin, M., and Martin, R. V.: Sources of carbonaceous aerosols over the United States and implications for natural visibility, J. Geophys. Res., 108, 4355, doi:10.1029/2002jd003190, 2003.

Park, R. J., Jacob, D. J., Field, B. D., Yantosca, R. M., and Chin, M.: Natural and transboundary pollution influences on sulfate-nitrate-ammonium aerosols in the United States: implications for policy, J. Geophys. Res., 109, D15204, doi:10.1029/2003jd004473, 2004.

Partridge, D. G., Vrugt, J. A., Tunved, P., Ekman, A. M. L., Gorea, D., and Sorooshian, A.: Inverse modeling of cloud-aerosol interactions - Part 1: Detailed response surface analysis, Atmos. Chem. Phys., 11, 7269-7287, doi:10.5194/acp-11-7269-2011, 2011.

Pöschl, U., Martin, S. T., Sinha, B., Chen, Q., Gunthe, S. S., Huffman, J. A., Borrmann, S., Farmer, D. K., Garland, R. M., Helas, G., Jimenez, J. L., King, S. M., Manzi, A., Mikhailov, E., Pauliquevis, T., Petters, M. D., Prenni, A. J., Roldin, P., Rose, D., Schneider, J., Su, H., Zorn, S. R., Artaxo, P., and Andreae, M. O.: Rainforest Aerosols as Biogenic Nuclei of Clouds and Precipitation in the Amazon, Science, 329, 1513-1516, 2010.

Price, C. and Rind, D.: A simple lightning parameterization for calculating global lightning distributions, J. Geophys. Res., 97, 9919-9933, 1992.

Prospero, J. M., Charlson, R. J., Mohnen, V., Jaenicke, R., Delany, A. C., Moyers, J., Zoller, W., and Rahn, K.: The atmospheric aerosol system - an overview, Rev. Geophys., 21, 16071629, 1983.

Pye, H. O. T., Liao, H., Wu, S., Mickley, L. J., Jacob, D. J., Henze, D. K., and Seinfeld, J. H.: Effect of changes in climate and emissions on future sulfate-nitrate-ammonium aerosol levels in the United States, J. Geophys. Res.-Atmos., 114, D01205, doi:10.1029/2008jd010701, 2009.

Rissman, T. A., Nenes, A., and Seinfeld, J. H.: Chemical amplification (or dampening) of the Twomey effect: conditions derived from droplet activation theory, J. Atmos. Sci., 61, 919-930, 2004.

Rotman, D. A., Tannahill, J. R., Kinnison, D. E., Connell, P. S., Bergmann, D., Proctor, D., Rodriguez, J. M., Lin, S. J., Rood, R. B., Prather, M. J., Rasch, P. J., Considine, D. B., Ramaroson, R., and Kawa, S. R.: Global Modeling Initiative assessment model: model description, integration, and testing of the transport shell, J. Geophys. Res., 106, 1669-1691, doi:10.1029/2000jd900463, 2001.

Saide, P. E., Carmichael, G., Spak, S. N., Minnis, P., and Ayers, J. K.: Improving aerosol distributions below clouds by assimilating satellite-retrieved cloud droplet number, P. Natl. Acad. Sci. USA, 109, 11939-11943, doi:10.1073/pnas.1205877109, 2012.
Sandu, A., Liao, W., Carmichael, G. R., Henze, D. K., and Seinfeld, J. H.: Inverse modeling of aerosol dynamics using adjoints: theoretical and numerical considerations, Aerosol Sci. Tech., 39, 677-694, doi:10.1080/02786820500182289, 2005.

Sasaki, Y.: Some basic formalisms in numerical variational analysis, Mon. Weather Rev., 98, 875-883, doi:10.1175/15200493(1970)098<0875:SBFINV> 2.3.CO;2, 1970.

Segal, Y. and Khain, A.: Dependence of droplet concentration on aerosol conditions in different cloud types: application to droplet concentration parameterization of aerosol conditions, J. Geophys. Res., 111, D15204, doi:10.1029/2005jd006561, 2006.

Seifert, A. and Beheng, K. D.: A two-moment cloud microphysics parameterization for mixed-phase clouds. Part 1: model description, Meteorol. Atmos. Phys., 92, 45-66, doi:10.1007/s00703005-0112-4, 2006.

Sotiropoulou, R. E. P., Medina, J., and Nenes, A.: CCN predictions: is theory sufficient for assessments of the indirect effect?, Geophys. Res. Lett., 33, L05816, doi:10.1029/2005g1025148, 2006.

Sotiropoulou, R. E. P., Nenes, A., Adams, P. J., and Seinfeld, J. H.: Cloud condensation nuclei prediction error from application of Köhler theory: importance for the aerosol indirect effect, J. Geophys. Res., 112, D12202, doi:10.1029/2006jd007834, 2007.

Spracklen, D. V., Pringle, K. J., Carslaw, K. S., Chipperfield, M. P., and Mann, G. W.: A global off-line model of size-resolved aerosol microphysics: II. Identification of key uncertainties, Atmos. Chem. Phys., 5, 3233-3250, doi:10.5194/acp-5-3233-2005, 2005.

Streets, D. G., Zhang, Q., Wang, L. T., He, K. B., Hao, J. M., Wu, Y., Tang, Y. H., and Carmichael, G. R.: Revisiting China's CO emissions after the Transport and Chemical Evolution over the Pacific (TRACE-P) mission: synthesis of inventories, atmospheric modeling, and observations, J. Geophys. Res., 111, D14306, doi:10.1029/2006jd007118, 2006.

van Donkelaar, A., Martin, R. V., Leaitch, W. R., Macdonald, A. M., Walker, T. W., Streets, D. G., Zhang, Q., Dunlea, E. J., Jimenez, J. L., Dibb, J. E., Huey, L. G., Weber, R., and Andreae, M. O.: Analysis of aircraft and satellite measurements from the Intercontinental Chemical Transport Experiment (INTEX-B) to quantify long-range transport of East Asian sulfur to Canada, Atmos. Chem. Phys., 8, 2999-3014, doi:10.5194/acp-8-2999-2008, 2008.

Vukićević, T. and Hess, P.: Analysis of tropospheric transport in the Pacific basin using the adjoint technique, J. Geophys. Res., 105, 7213-7230, doi:10.1029/1999jd901110, 2000.

Wang, Y. H., Jacob, D. J., and Logan, J. A.: Global simulation of tropospheric $\mathrm{O}_{3}-\mathrm{NO}_{\mathrm{x}}$-hydrocarbon chemistry 1 . model formulation, J. Geophys. Res., 103, 10713-10725, doi:10.1029/98jd00158, 1998.

Wang, Y. X. X., McElroy, M. B., Jacob, D. J., and Yantosca, R. M.: A nested grid formulation for chemical transport over Asia: applications to CO, J. Geophys. Res., 109, D22307, doi:10.1029/2004jd005237, 2004.

van der Werf, G. R., Morton, D. C., DeFries, R. S., Giglio, L., Randerson, J. T., Collatz, G. J., and Kasibhatla, P. S.: Estimates of fire emissions from an active deforestation region in the southern Amazon based on satellite data and biogeochemical modelling, Biogeosciences, 6, 235-249, doi:10.5194/bg-6-235-2009, 2009.

Wesely, M. L.: Parametirization of surface resistances to gaseous dry deposition in regional-scale numerical-models, Atmos. Envi- 
ron., 23, 1293-1304, doi:10.1016/0004-6981(89)90153-4, 1989. Woodhouse, M. T., Carslaw, K. S., Mann, G. W., Vallina, S. M., Vogt, M., Halloran, P. R., and Boucher, O.: Low sensitivity of cloud condensation nuclei to changes in the sea-air flux of dimethyl-sulphide, Atmos. Chem. Phys., 10, 7545-7559, doi:10.5194/acp-10-7545-2010, 2010.

Yienger, J. J. and Levy, H.: Empirical-model of global soilbiogenic $\mathrm{NO}_{\mathrm{x}}$ emissions J. Geophys. Res., 100, 11447-11464, doi:10.1029/95jd00370, 1995.
Zhang, W., Capps, S. L., Hu, Y., Nenes, A., Napelenok, S. L., and Russell, A. G.: Development of the high-order decoupled direct method in three dimensions for particulate matter: enabling advanced sensitivity analysis in air quality models, Geosci. Model Dev., 5, 355-368, doi:10.5194/gmd-5-355-2012, 2012. 